\title{
Successful Aging in Small Enterprises: Entrepreneurship, Job Demands-Resources, and Health
}

\author{
Chao Miao \\ cxmiao@salisbury.edu | Department of Management and Marketing, Franklin P. Perdue School of \\ Business, Salisbury University, Salisbury, Maryland, USA \\ Shanshan Qian \\ sqian@towson.edu | Department of Management, College of Business and Economics, Towson \\ University, Towson, Maryland, USA \\ Ronald H. Humphrey \\ r.humphrey@lancaster.ac.uk | Department of Entrepreneurship and Strategy, Lancaster University \\ Management School, Lancaster University, Lancaster, United Kingdom

\section{Letter from Academia}

\begin{abstract}
Successful aging at work is an important topic which is pertinent to everyone who works to make a living because getting older is unavoidable. The objective of this paper is to draw on Job Demands-Resources (JD-R) model to explore successful aging in the field of entrepreneurship. A conceptual approach was used to examine the successful aging in the field of entrepreneurship. Building on JD-R model, older workers who pursue entrepreneurship may have improved mental and physical health and obtain successful aging at work. The current study developed a theoretical foundation to explore successful aging in the field of entrepreneurship and offered suggestions for future research.
\end{abstract}

Keywords. Entrepreneurship; Successful Aging.

Cite paper as: Miao, C., Qian, S., Humphrey, R., (2020). Successful Aging in Small Enterprises: Entrepreneurship, Job Demands-Resources, and Health - Letter from Academia, Journal of Innovation Management, www.open-jim.org, 8(2), 11-15. 


\section{Introduction}

The research regarding successful aging at work is a critical topic for everyone who works to earn a living in that getting older is inevitable (Kooij, Zacher, Wang, \& Heckhausen, 2020). Recently, a comprehensive process model was proposed to explain the antecedents and mechanisms which lead to successful aging at work (Kooij et al., 2020). In spite of the comprehensiveness of their process model, one important missing piece is regarding the successful aging in the field of entrepreneurship. We believe this missing piece deserves attention for two reasons.

First, senior entrepreneurship has become a critical topic due to the aging workforce (Stypinska, Franke, \& Myrczik, 2019). For example, it is predicted that the population of the people aged 65 and older will be more than that of the people aged 18 and younger by 2035 in the U.S. (McLennan, 2018). Second, one assumption of the successful aging at work discussed in Kooij et al. (2020) is that older workers have to handle age-related losses (e.g., physical health) and that the factors which will help older workers to properly deal with these age-related losses may contribute to successful aging at work. Recently, some entrepreneurship studies indicated that pursuing entrepreneurship may allow one to acquire job resources and to improve health and well-being (e.g., Nikolova, 2019), which may result in successful aging at work.

In the following sections, we will draw on the Job Demands-Resources (JD-R) model to explain how entrepreneurial activities may lead to increased job resources and to improve health and well-being to enable older workers to continue working.

\section{JD-R Model}

The JD-R model suggests that every occupation has its own risk factors related to job stress and these factors can be categorized into two types: job demands and job resources (Bakker \& Demerouti, 2007). Job demands will result in psychological and/or physiological costs because job demands require sustained psychological and/or physical efforts whereas job resources will help to reduce job demands, foster personal growth, development, and learning, and facilitate the accomplishment of work goals (Bakker \& Demerouti, 2007). Prior research demonstrated that preserving job resources will help one to achieve work goals and will lead to positive attitudinal and health-related outcomes (e.g., Crawford, LePine, \& Rich, 2010; Miao, Humphrey, \& Qian, 2017).

\section{Entrepreneurship, Job Resources, and Health}

Although entrepreneurship research typically focuses on firm-level outcomes (e.g., firm performance), there is a growing body of research which aims at well-being and fulfillment because idiosyncratic and personal reasons explain why individuals engage in entrepreneurship (Wiklund et al., 2019).

Research has shown that pursuing entrepreneurship (a type of "active jobs") may lead to improved mental health and physical health because one may enjoy greater autonomy, flexibility, and 
being their own boss, learn and develop new skills to better him/herself, and develop a feeling of mastery (Nikolova, 2019). Hence, these acquired benefits as a result of self-employment (i.e., job resources) may stimulate older workers who pursue entrepreneurship to develop self-regulation behaviors and self-initiate changes in the job to improve person-job fit, thus leading to successful aging at work (Kooij et al., 2020). Therefore, older workers who pursue entrepreneurship may not only enjoy improved mental and physical health but also achieve successful aging at work.

\section{Recommendations for Future Research}

We encourage future research to apply Kooij et al.'s (2020) process model of successful aging at work to the field of entrepreneurship in order to develop a better understanding of senior entrepreneurship. This cross-disciplinary investigation will bring mutual benefits. For the field of industrial and organizational psychology (I/O psychology), I/O psychologists may test the process model of successful aging at work in a unique context and may examine whether the major theoretical propositions in the process model will still work in entrepreneur samples. This may also open avenues for $\mathrm{I} / \mathrm{O}$ researchers to revise and improve the process model to enhance its external validity. From practical standpoints, I/O psychologists can also serve as mentors and/or consultants for senior entrepreneurs to help them better navigate their work life and devise their career plan to increase their chances of successful aging at work.

There are incessant calls for more research to examine entrepreneurial well-being (Wiklund et al., 2019). For the field of entrepreneurship, entrepreneurship researchers may apply the process model of successful aging at work to better comprehend how senior entrepreneurs can develop better well-being through the factors and mechanisms as discussed in the process model. We also argue that this line of investigation may enhance the current understanding of social entrepreneurship because senior entrepreneurs typically have more socially oriented goals to operate their enterprises (Stypinska et al., 2019). In terms of practical implications, policy makers may follow the evidence-based advices provided by entrepreneurship researchers to create favorable environments and frameworks to promote entrepreneurship among older workers.

\section{References}

Bakker, A. B., \& Demerouti, E. (2007). The job demands-resources model: State of the art. Journal of Managerial Psychology, 22, 309-328.

Crawford, E. R., LePine, J. A., \& Rich, B. L. (2010). Linking job demands and resources to employee engagement and burnout: A theoretical extension and meta-analytic test. Journal of Applied Psychology, 95, 834-848.

Kooij, D. T., Zacher, H., Wang, M., \& Heckhausen, J. (2020). Successful aging at work: A process model to guide future research and practice. Industrial and Organizational Psychology: Perspectives on Science and Practice. 
McLennan, J. (2018). How and why entrepreneurs should focus on seniors in 2019. Retrieved from https://www.entrepreneur.com/article/325261

Miao, C., Humphrey, R. H., \& Qian, S. (2017). A meta-analysis of emotional intelligence and work attitudes. Journal of Occupational and Organizational Psychology, 90, 177-202.

Nikolova, M. (2019). Switching to self-employment can be good for your health. Journal of Business Venturing, 34, 664-691.

Stypinska, J., Franke, A., \& Myrczik, J. (2019). Senior entrepreneurship: The unrevealed driver for social innovation. Frontiers in Sociology, 4, Article 30.

Wiklund, J., Nikolaev, B., Shir, N., Foo, M. D., \& Bradley, S. (2019). Entrepreneurship and well-being: Past, present, and future. Journal of Business Venturing, 34, 664-691. 


\section{Biographies}

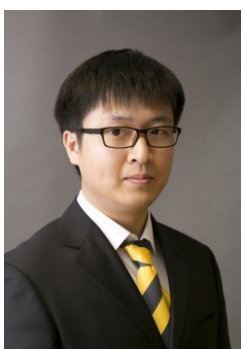

Chao Miao. Chao Miao, Ph.D., is an Assistant Professor of Management in the Department of Management and Marketing, Franklin P. Perdue School of Business, Salisbury University. He has published in Entrepreneurship Theory and Practice, Human Resource Management Review, Journal of Business Research, Journal of Occupational and Organizational Psychology, Journal of Small Business Management, Journal of World Business, Marketing Letters, Personality and Individual Differences, Small Business Economics, and other journals.

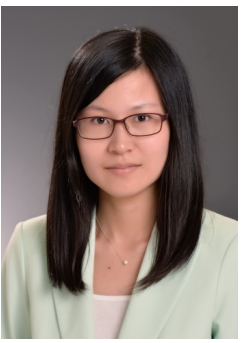

Shanshan Qian. Shanshan Qian, Ph.D., is an Assistant Professor of Entrepreneurship in the Department of Management, College of Business and Economics, Towson University. She has published in Entrepreneurship Theory and Practice, Human Resource Management Review, Journal of Business Research, Journal of Occupational and Organizational Psychology, Journal of Research in Personality, Journal of Small Business Management, Journal of World Business, Marketing Letters, Small Business Economics, and other journals.

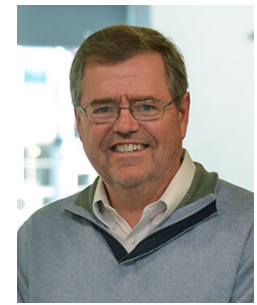

Ronald H. Humphrey. Ronald H. Humphrey, Ph.D., is a Distinguished Professor of Leadership in the Department of Entrepreneurship and Strategy, Lancaster University Management School, Lancaster University, United Kingdom. He is the author of Effective Leadership: Theory, Cases, and Applications (2013). He has published in Academy of Management Review, Academy of Management Perspectives, American Sociological Review, Human Relations, Journal of Occupational and Organizational Psychology, Journal of Organizational Behavior, Journal of World Business, Leadership Quarterly, Organization Science, Research in Organizational Behavior, Social Psychology Quarterly, and other journals.

\section{ISSN 2183-0606}

